\title{
Digestibility and nitrogen balance of lambs fed sugarcane hydrolyzed under different conditions as roughage in the diet
}

\author{
Digestibilidade e balanço de nitrogênio em cordeiros alimentados com cana-de-açúcar hidrolisada \\ em diferentes condições como volumoso na dieta
}

\author{
Viviane Endo $^{I^{*}}$ Américo Garcia da Silva Sobrinho ${ }^{\mathrm{I}}$ Fabiana Alves de Almeida \\ Natália Ludmila Lins Lima ${ }^{\mathrm{I}}$ Nivea Maria Brancacci Lopes Zeola ${ }^{\mathrm{I}}$
}

\section{ABSTRACT}

This study aimed to evaluate the digestibility and nitrogen balance $(N B)$ of lambs fed sugarcane hydrolyzed under different conditions. Fifteen Ile de France lambs at, on average, $23.5 \mathrm{~kg}$ of body weight were evaluated. Treatments were: in natura sugarcane (IN), sugarcane hydrolyzed using $0.6 \%$ calcium oxide $(\mathrm{CaO})$ under aerobic condition (AER), and sugarcane hydrolyzed using $0.6 \% \mathrm{CaO}$ under anaerobic condition (ANA). Therefore, a completely randomized design was constituted with five replicates per treatment. Treatments were supplied to animals along with concentrate. Both hydrolysis conditions aimed to alter the sugarcane fermentation pattern, therefore improving fiber digestibility. Lambs were housed in individual pens and fed with diet allowing $10 \%$ of refusals. Refusals, feces and urine were sampled daily during five days. They were collected to determine the digestibility and NB. A higher digestibility of neutral detergent fiber corrected for ash and protein (57.05\%), organic matter (85.39\%), hemicellulose (72.09\%), NB (29.46g day $\mathrm{y}^{-1}$ and $\left.2.78 \mathrm{~g} \mathrm{~kg}^{-0.75} \mathrm{day}^{-1}\right)$ and rate of nitrogen absorbed (3.00 $\mathrm{kg}^{-0.75}$ day $\left.^{-1}\right)$ were observed for lambs fed with ANA than for those fed IN $(41.17 \%, 73.76 \%, 53.80 \%, 21.39 \mathrm{~g}$ day $^{-1}, 2.00 \mathrm{~g} \mathrm{~kg}^{-0.75} \mathrm{day}^{-1}$ and $2.22 \mathrm{~g} \mathrm{~kg}^{-0.75}$ day $^{-1}$, respectively). As roughage, ANA in the lamb diet, optimizes the nitrogen balance and is more efficient to improve the digestibility of some nutrients compared to IN. Whereas AER was as efficient as ANA and IN.

Key words: condition of hydrolysis, neutral detergent fiber, nitrogen retained.

RESUMO

O objetivo deste estudo foi avaliar a digestibilidade e o balanço de nitrogênio (BN) do volumoso cana-de-açúcar hidrolisada sob diferentes condições, na alimentação de cordeiros. Foram utilizados 15 cordeiros Ile de France, em média, com 23,5kg de peso corporal. Os tratamentos foram: cana-de-açúcar in natura, cana-de-açúcar hidrolisada com 0,6\% de óxido de cálcio ( $\mathrm{CaO}$ ), sob condição aeróbica e cana-de-açúcar hidrolisada, com 0,6\% de $\mathrm{CaO}$, sob condição anaeróbica, constituindo um delineamento inteiramente casualizado com cinco repetições por tratamento. Os tratamentos foram fornecidos aos animais, juntamente com o concentrado. Ambas as condições das hidrólises tiveram o intuito de alterar o padrão de fermentação da cana-de-açúcar e, com isso, melhorar a digestibilidade de suas fibras. Os cordeiros foram confinados em baias individuais e a dieta foi fornecida permitindo $10 \%$ de sobras. Estas sobras foram amostradas diariamente por cinco dias, bem como as fezes e urina foram coletadas para determinar a digestibilidade e o BN. Foi observado, para cordeiros alimentados com ANA, maior digestibilidade da fibra em detergente neutro, corrigido para proteína e cinzas $(57,05 \%)$, matéria orgânica (85,39\%), hemicelulose (72,09\%), maior BN $\left(29,46 \mathrm{~g}\right.$ dia $^{-1}$ e 2,78g $\mathrm{kg}^{-0,75}$ dia $\left.^{-1}\right)$ e taxa de nitrogênio absorvido $\left(3,00 \mathrm{~g} \mathrm{~kg}^{-0,75} \mathrm{dia}^{-1}\right)$, em comparação ao IN (41,17\%, 73,76\% e 53,80\%, 21,39g dia-1, 2,00g $\mathrm{kg}^{-0.75} \mathrm{dia}^{-1}$ e 2,22 $\mathrm{g} \mathrm{kg}^{-0.75} \mathrm{dia}^{-1}$, respectivamente). Como volumoso, ANA otimiza o balanço de nitrogênio e é mais eficiente em melhorar a digestibilidade de alguns nutrientes, comparado à IN. AER tão eficiente quanto ANA e IN.

Palavras-chave: condição de hidrólise, fibra em detergente neutro, nitrogênio retido.

\section{INTRODUCTION}

Sugarcane is a tropical roughage widely used in cattle feed. It has several positive aspects: easily cultivated, high content of energy, and high potential of dry matter production per unit of area, especially when forage is scarce. It has, however, few drawbacks: low crude protein content that requires protein supplementation and a need for daily cut due to the high concentration of soluble carbohydrates. The high concentration of soluble

IFaculdade de Ciências Agrárias e Veterinárias, Universidade Estadual Paulista (UNESP), 14884-900, Jaboticabal, SP, Brasil. E-mail: endo_vica@hotmail.com.*Corresponding author. 
carbohydrates makes the environment auspicious for the development of microorganisms that deteriorate the chopped sugarcane. To overcome this issue, hydrolysis using alkalizing treatments, e.g. calcium oxide $(\mathrm{CaO})$, has been promoted on sugarcane, which can also improve the nutritive value of sugarcane by increasing the digestibility of fibers (CARVALHO et al., 2011). The alkalizing agents act in the hydrolysis solubilizing part of the hemicellulose and promoting the expansion of the cellulose molecules. This expansion causes the breaking of the hydrogen bonds between cellulose and hemicellulose, increasing their digestibility. Measurements to qualify food regarding its nutritive value are expressed by the digestibility coefficient which indicates the percentage of each nutrient that an animal is capable of using (BERCHIELLI et al., 2011). Hydrolyzed sugarcane showed an improvement of $6.61 \%$ in the in vitro dry matter digestibility, $12.95 \%$ for the neutral detergent fiber and $9.28 \%$ for the acid detergent fiber (OLIVEIRA, 2010). $\mathrm{CaO}$ improves the sugarcane nutritive value and because it is an alkaline additive, it can alter the ruminal environment and change the fermentation pattern, which reduces the metabolism and the nitrogen balance (CARVALHO et al., 2011).

A $\mathrm{pH}$ increase due to the application of $\mathrm{CaO}$ in sugarcane, followed by a gradual $\mathrm{pH}$ decrease due to aerobic exposure of sugarcane occurs during the hydrolysis. This decrease is linear but not desired, because the $\mathrm{pH}$ decrease occurs by action of aerobic microorganisms. These microorganisms consume the soluble carbohydrates and cause acidification of sugarcane (RABELO et al., 2011). With the hydrolysis of sugarcane under anaerobic condition, i.e. without exposure to oxygen, theoretically, in the course of time, $\mathrm{pH}$ decreases slower than in the hydrolysis under aerobic exposure, which may result in a less favorable environment for the development of aerobic microorganisms. The objective of this study was to evaluate the influence of aerobic and anaerobic conditions on hydrolyzed sugarcane as roughage in the diet, over the digestibility of nutrients and nitrogen balance of lambs.

\section{MATERIAL AND METHODS}

Fifteen uncastrated Ile de France lambs at a mean body weight of $23.5 \pm 1.3 \mathrm{~kg}$ were used. Lambs were housed in individual digestibility pens $\left(1.0 \mathrm{~m}^{2}\right)$, with suspended floor and were distributed in a completely randomized design with three treatments and five replicates: in natura sugarcane+concentrate (IN), sugarcane hydrolyzed using $0.6 \% \mathrm{CaO}$ under aerobic or anaerobic condition+concentrate (AER or ANA). Chemical composition of the ingredients is shown in table 1 and composition, percentage and chemical analysis of diets are in table 2. Diets were formulated according to NRC (2007) for lamb weight

Table 1 - Chemical and crude energy composition of the ingredients of the experimental diets (expressed on DM).

\begin{tabular}{|c|c|c|c|c|c|}
\hline \multirow[t]{2}{*}{ Chemical composition (on DM) } & \multicolumn{3}{|c|}{----------------Hydrolyzedusing $\mathrm{CaO}$ (0.6\%)-------------- } & \multirow[t]{2}{*}{ Soybean meal } & \multirow[t]{2}{*}{ Ground corn } \\
\hline & In natura & Aerobic & Anaerobic & & \\
\hline Dry matter $(\%)$ & 33.75 & 30.64 & 30.71 & 90.18 & 89.80 \\
\hline Organic matter $(\%)$ & 32.01 & 27.06 & 26.78 & 83.29 & 87.39 \\
\hline Mineral matter $(\%)$ & 1.74 & 3.58 & 3.93 & 6.89 & 2.41 \\
\hline Crude protein $(\%)$ & 1.51 & 1.49 & 1.46 & 47.50 & 10.48 \\
\hline Ether extract $(\%)$ & 1.85 & 1.45 & 1.27 & 1.75 & 6.85 \\
\hline Lignin (\%) & 5.63 & 5.19 & 5.53 & 7.75 & 2.51 \\
\hline Neutral detergent fiber $(\%)^{1}$ & 41.09 & 37.54 & 37.67 & 20.89 & 10.11 \\
\hline Neutral detergent acid $(\%)^{2}$ & 22.90 & 20.10 & 20.11 & 8.51 & 2.70 \\
\hline Hemicellulose (\%) & 18.19 & 17.44 & 17.56 & 12.38 & 7.41 \\
\hline Cellulose (\%) & 17.27 & 14.91 & 0.76 & 7.60 & 0.19 \\
\hline Total carbohydrates $(\%)^{3}$ & 95.87 & 92.72 & 94.29 & 43.87 & 80.25 \\
\hline Non-fibrous carbohydrates $(\%)^{4}$ & 53.81 & 55.94 & 55.67 & 22.97 & 70.15 \\
\hline Crude energy (Mcal kg-1) & 3.88 & 3.70 & 3.82 & 4.56 & 4.37 \\
\hline
\end{tabular}

${ }^{1}$ Neutral detergent fiber corrected for ash and protein. ${ }^{2}$ Acid detergent fiber corrected for ash and protein. ${ }^{3}$ Total carbohydrates $=100-$ $(\% \mathrm{CP}+\% \mathrm{EE}+\% \mathrm{MM}) .{ }^{4}$ Non-fiber carbohydrates $=100-(\% \mathrm{NDFap}+\% \mathrm{CP}+\% \mathrm{EE}+\% \mathrm{MM})$.

Source: elaboration of the authors.

Ciência Rural, v.45, n.2, fev, 2015. 
Table 2 - Ingredients percentage, chemical and crude energy composition of the experimental diets (expressed in DM).

\begin{tabular}{|c|c|c|c|}
\hline \multirow{2}{*}{ Ingredients $(\%)$} & \multicolumn{3}{|c|}{ 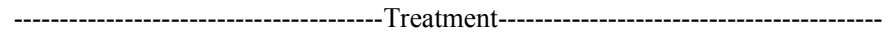 } \\
\hline & $\mathrm{IN}$ & AER & ANA \\
\hline Sugarcane & 49.93 & 52.69 & 50.99 \\
\hline Urea & 1.27 & 1.20 & 1.21 \\
\hline Ground corn & 8.09 & 7.64 & 7.76 \\
\hline Soybean meal & 37.97 & 35.87 & 36.41 \\
\hline Sodium chloride & 0.33 & 0.31 & 0.31 \\
\hline Limestone & 1.15 & 1.08 & 1.10 \\
\hline Phosphate dicalcium & 0.80 & 0.76 & 0.77 \\
\hline Mineral mixture ${ }^{1}$ & 0.47 & 0.44 & 0.45 \\
\hline & omposit & - & - \\
\hline Dry matter $(\%)$ & 50.07 & 47.31 & 48.01 \\
\hline Crude protein $(\%)$ & 22.73 & 21.48 & 21.80 \\
\hline Mineral matter (\%) & 6.24 & 6.96 & 7.19 \\
\hline Neutral detergent fiber $(\%)^{2}$ & 27.53 & 28.15 & 29.79 \\
\hline Acid detergent fiber $(\%)^{3}$ & 13.17 & 13.56 & 14.92 \\
\hline Hemicellulose (\%) & 14.36 & 14.59 & 14.87 \\
\hline Cellulose (\%) & 7.48 & 7.85 & 9.03 \\
\hline Lignin (\%) & 5.69 & 5.71 & 5.89 \\
\hline Ether extrate $(\%)$ & 2.14 & 1.92 & 1.83 \\
\hline Total carbohydrates $(\%)^{4}$ & 68.89 & 68.72 & 69.18 \\
\hline Non-fiber carbohydrates $(\%)^{5}$ & 41.36 & 40.57 & 39.39 \\
\hline Crude energy (Mcal kg ${ }^{-1}$ ) & 4.02 & 3.92 & 3.99 \\
\hline
\end{tabular}

$\mathrm{IN}=$ in natura sugarcane + concentrate, $\mathrm{AER}=$ sugarcane hydrolyzed using $0.6 \% \mathrm{CaO}$ under aerobic conditions + concentrate, ANA $=$ sugarcane hydrolyzed using $0.6 \% \mathrm{CaO}$ under anaerobic conditions + concentrate. ${ }^{1}$ Mineral mixture: zinc $1600 \mathrm{mg}$, copper $300 \mathrm{mg}$, manganese $1500 \mathrm{mg}$, iron $1100 \mathrm{mg}$, cobalt $10 \mathrm{mg}$, iodine $27 \mathrm{mg}$, selenium $22 \mathrm{mg}$. ${ }^{2}$ Neutral detergent fiber corrected for ash and protein. ${ }^{3}$ Acid detergent fiber corrected for ash and protein. ${ }^{4}$ Total carbohydrates $=100-(\% \mathrm{CP}+\% \mathrm{EE}+\% \mathrm{MM})$. ${ }^{5}$ Non-fiber carbohydrates $={ }^{100}$ $(\% \mathrm{NDFap}+\% \mathrm{CP}+\% \mathrm{EE}+\% \mathrm{MM})$.

Source: elaboration of the authors.

gain of $250 \mathrm{~g} \mathrm{day}^{-1}$, with a roughage to concentrate ratio of 50:50.

Lime consisted of a chemical composition of $93.4 \% \mathrm{CaO}, 0.6 \%$ of magnesium oxide and $0.1 \%$ phosphorus. The IAC 86-2480 was the variety of sugarcane used. A second cut of sugarcane with nine months of growing, non-defoliated and chopped in particle size of $1.0 \mathrm{~cm}$ was provided in natura and hydrolyzed under aerobic or anaerobic conditions, depending on the treatment. In natura sugarcane was cut daily and was kept for 2-day ripening, after that, it was chopped and provided to the lambs. Hydrolyzed sugarcane was cut daily, chopped and treated using $0.6 \% \mathrm{CaO}$ per $100 \mathrm{~kg}$ of sugarcane. A solution was made according to OLIVEIRA (2010). Sugarcane remained under aerobic and anaerobic conditions for 2-day ripening before being provided to the lambs. The hydrolyzed sugarcane was obtained by chopping and spreading it on a tarp, forming a stack. Calcium oxide solution was poured over the sugarcane, and the stack was revolved for homogenization. The stack of sugarcane hydrolyzed under aerobic condition remained on the tarp. Whereas, sugarcane hydrolyzed under anaerobic condition was stored in screw-top drums, which avoided the contact of oxygen with the hydrolyzed sugarcane.

Lambs received a mixed diet at the feeder, generating $10 \%$ of refusals. Diets were offered twice a day, at 8 and 17 hours. The trial lasted 20 days, which 15 days were used for adaptation and five days to total feces and urine collection under mensuration of feed intake (Table 3). Daily amount of excreted feces was collected in plastic bowls and weighed using a digital scale. Urine was collected in beveled plastic buckets with a protecting net avoiding the entry of feces. A total of $100 \mathrm{~mL}$ of a $20 \%$ solution of $\mathrm{H}_{2} \mathrm{SO}_{4}$ was added in the buckets to prevent the volatilization of the ammonia in the urine.

A total of $10 \%$ of the feed refusals, excreted urine and feces were sampled daily. Samples were stored in a $-18^{\circ} \mathrm{C}$ freezer until the end of collection period for subsequent laboratory analyses. 
Table 3 - Nutrient intake based on dry matter of lambs fed diets containing sugarcane either in natura or hydrolyzed under aerobic and anaerobic conditions.

\begin{tabular}{|c|c|c|c|c|}
\hline & \multicolumn{3}{|c|}{ 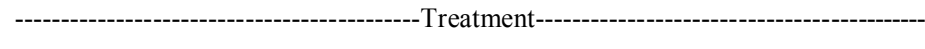 } & \multirow{2}{*}{$\operatorname{Pr}>F$} \\
\hline & IN & AER & ANA & \\
\hline Body Weight (kg) & $23.18 \pm 0.47$ & $23.69 \pm 0.87$ & $23.68 \pm 0.27$ & ns \\
\hline Weight gain $(\mathrm{kg})$ & $0.264 \pm 0.14$ & $0.276 \pm 0.08$ & $0.140 \pm 0.09$ & ns \\
\hline & ------------------- & nt intake $\left(\mathrm{g}_{\text {day }}{ }^{-1}\right.$ & & \\
\hline Dry matter & $952,20 \pm 0.02$ & $988,00 \pm 0.04$ & $1014,00 \pm 0.02$ & ns \\
\hline Organic matter & $800.91 \pm 42.17$ & $848.16 \pm 74.47$ & $872.84 \pm 39.36$ & ns \\
\hline Neutral detergent fiber ${ }^{1}$ & $242.29 \pm 16.25$ & $257.37 \pm 22.44$ & $294.09 \pm 11.91$ & ns \\
\hline Acid detergent fiber ${ }^{2}$ & $132.83 \pm 9.70$ & $120.56 \pm 10.70$ & $126.69 \pm 4.10$ & ns \\
\hline Lignin & $88.89 \pm 6,25$ & $91.96 \pm 8,48$ & $103.43 \pm 3.69$ & ns \\
\hline Hemicellulose & $129.13 \pm 8.12$ & $136.05 \pm 11.68$ & $146.20 \pm 7.40$ & ns \\
\hline Cellulose & $96.06 \pm 7.03$ & $83.56 \pm 6.88$ & $86.39 \pm 3.29$ & ns \\
\hline
\end{tabular}

IN: in natura sugarcane + concentrate, AER: sugarcane hydrolyzed using $0.6 \% \mathrm{CaO}$ under aerobic condition + concentrate, ANA: sugarcane hydrolyzed using $0.6 \% \mathrm{CaO}$ under anaerobic condition + concentrate. Tukey test $(*=\mathrm{P}<0.05$, ns $=$ non-signicance $)$. ${ }^{1}$ Neutral detergent fiber corrected for ash and protein. ${ }^{2}$ Acid detergent fiber corrected for ash and protein.

Source: authors' elaboration.

Posteriorly, samples were pre-dried in a forcedventilation and milled with $1 \mathrm{~mm}$ grinding plates. The milled samples were used to determine the contents of dry (DM) and organic matter (OM) following AOAC (1990) methodologies. The contents of neutral detergent fiber (NDFap), acid detergent fiber (ADFap) corrected for ash and protein, hemicellulose (HEM), cellulose (CEL) and lignin (LIG) corrected for ash were determined according to VAN SOEST et al. (1991).

Digestibility's of DM, OM, NDFap, ADFap, HEM, CEL and LIG were calculated using the following formula: apparent digestibility, AD $(\%)=[($ nutrient intake $(\mathrm{g})$ - nutrient excretion $(\mathrm{g})) /$ nutrient intake $(\mathrm{g})]^{*} 100$. The nitrogen balance (NB) was expressed in $\mathrm{g} \mathrm{kg}^{-0.75} \mathrm{day}^{-1}$, and was calculated using the following equations ( $\mathrm{N}=$ Nitrogen): $\mathrm{NB}$ or $\mathrm{N}_{\text {retained }}=\mathrm{N}_{\text {intake }}-\left(\mathrm{N}_{\text {feces }}+\mathrm{N}_{\text {urine }}\right), \mathrm{N}_{\text {absorbed }}=\mathrm{N}_{\text {intake }}-$ $\mathrm{N}_{\text {feces }}$ and $\mathrm{N}_{\text {intake }}=\mathrm{N}_{\text {offered }}-\mathrm{N}_{\text {refusals }}$.

A completely randomized experimental design with three treatments and five replicates were used. Data were subjected to analysis of variance by PROC GLM using the statistical software (SAS, 2001 ), at $5 \%$ significance level. When significant differences were detected, means were tested by Tukey HSD range test at 5\% significance level.

\section{RESULTS AND DISCUSSION}

The hydrolysis of sugarcane provides a better use of the fibers by the ruminal microorganisms. In this study, it was assessed the influence of the AER and ANA conditions on the sugarcane hydrolysis regarding digestibility parameters and the NB.

Lambs fed AER and ANA did not have significantly higher $(\mathrm{P}>0.05)$ digestibility of $\mathrm{DM}$, ADFap, and CEL compared to lambs fed IN (Table 4). No difference for CEL was observed, however a higher digestibility of LIG was observed for lambs fed with AER than lambs fed IN. ADFap, which is constituted by cellulose and lignin, showed lower lignin than cellulose content on sugarcane, therefore the difference observed for LIG digestibility was not sufficient to influence the digestibility of ADFap. Lignin, which digestibility is either null or very low (MARAIS, 2000), is a factor that can restrict the digestion of fiber carbohydrates (e.g. hemicellulose) because they are chemically bound. SUNDSTOL \& OWEN (1984) stressed that the lignin fraction can be solubilized by a high concentration of sodium hydroxide. Cleavage of lignin's phenyl propane bonds forming free phenolic groups can occur due to the high temperature during hydrolysis. Lambs fed with AER had a higher LIG digestibility, which could have been caused by the temperature during hydrolysis. The temperature for IN was $19.66^{\circ} \mathrm{C}$, whereas for AER was $29.90^{\circ} \mathrm{C}$ and for ANA was $21.90^{\circ} \mathrm{C}$.

Lambs fed IN had lower digestibility $(\mathrm{P}<0.05)$ of OM and NDFap than lambs fed ANA. There was an increase on digestibility of $38.57 \%$ for NDFap and of $15.76 \%$ for OM for lambs fed ANA compared to lambs fed IN. The OM of a feed is the complement of its non-organic portion, i.e. mineral matter (DETMANN et al., 2012). Therefore, the 
Table 4 - Digestibility's of: dry matter (DDM), organic matter (DOM), neutral detergent fiber corrected for ash and protein (DNDFap), acid detergent fiber (DADF), hemicelluloses (DHEM), cellulose (DCEL) lignin (DLIG), total carbohydrates (DTC) and non-fiber carbohydrates (DNFC) for lambs fed in natura sugarcane or sugarcane hydrolyzed under aerobic or anaerobic conditions.

\begin{tabular}{|c|c|c|c|c|}
\hline \multirow{2}{*}{ Variable(g animal ${ }^{-1}$ day $\left.^{-1}\right)$} & \multicolumn{4}{|c|}{ 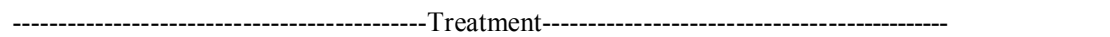 } \\
\hline & IN & AER & ANA & \\
\hline DDM & $67.90 \pm 5.53$ & $75.87 \pm 1.60$ & $77.84 \pm 2.38$ & ns \\
\hline DOM & $73.76^{\mathrm{b}} \pm 4.09$ & $81.58^{\mathrm{ab}} \pm 1.23$ & $85.39^{\mathrm{a}} \pm 2.52$ & * \\
\hline DNDFap & $41.17^{\mathrm{b}} \pm 8.64$ & $51.70^{\mathrm{ab}} \pm 2.55$ & $57.05^{\mathrm{a}} \pm 3.79$ & $*$ \\
\hline DADFap & $39.31 \pm 3.13$ & $35.08 \pm 3.80$ & $32.40 \pm 6.20$ & ns \\
\hline DHEM & $53.80^{\mathrm{b}} \pm 4.08$ & $66.41^{\mathrm{a}} \pm 2.70$ & $72.09^{\mathrm{a}} \pm 2.90$ & $*$ \\
\hline DCEL & $68.13 \pm 7.02$ & $73.78 \pm 2.71$ & $71.18 \pm 3.35$ & $\mathrm{~ns}$ \\
\hline DLIG & $23.28^{\mathrm{b}} \pm 5.49$ & $38.40^{\mathrm{a}} \pm 3.11$ & $34.20^{\mathrm{ab}} \pm 2.63$ & $*$ \\
\hline
\end{tabular}

$\mathrm{IN}=$ in natura sugarcane + concentrate, $\mathrm{AER}=$ sugarcane hydrolyzed using $0.6 \% \mathrm{CaO}$ under aerobic conditions + concentrate, $\mathrm{ANA}=$ sugarcane hydrolyzed using $0.6 \% \mathrm{CaO}$ under anaerobic conditions + concentrate. Tukey test $(*=\mathrm{P}<0.05$, ns $=$ non-significance $)$. Source: authors' elaboration.

higher NDFap, HEM and LIG digestibility's justify the higher OM digestibility for the ANA than the IN. For HEM digestibility, lambs fed AER (66.41\%) and ANA (72.09\%) had higher values than lambs fed IN $(53.80 \%)$. HEM acts as a bonding agent between CEL and LIG, therefore HEM was partly solubilized and the bonds were broken between CEL/HEM/LIG. The HEM digestibility had a higher influence than LIG digestibility on NDFap digestibility. This was observed when there was a higher digestibility of NDFap for the ANA than IN even when ANA only showed difference for HEM digestibility; the AER showed higher LIG and HEM digestibility's but no difference between NDFap.

FREITAS et al. (2008) who assessed nutrient digestibility in lambs found an increase of $18 \%$ and $22 \%$ for NDFap digestibility of hydrolyzed sugarcane $(0.5 \%$ and $0.9 \%$ calcium hydroxide, respectively) compared to IN. Whereas, in the current study, there was an increase of $25 \%$ and $38 \%$ for NDFap digestibility of AER and ANA, respectively, compared to IN. This variation in the effectiveness of NDFap digestibility can be explained by the variation in the chemical composition of the lime used by the aforementioned authors. Their lime had a minimum of $54 \% \mathrm{CaO}$, whereas the lime used in our study had a minimum of $93 \% \mathrm{CaO}$.

There was no difference $(\mathrm{P}>0.05)$ for $\mathrm{N}$ intake (36.46g animal ${ }^{-1}$ day $^{-1}$ and $3.43 \mathrm{~g} \mathrm{~kg}^{-0.75}$ day $^{-1}$ ), $\mathrm{N}$ excreted in the feces $\left(7.92 \mathrm{~g}^{-1}\right.$ animal $^{-1}$ day $^{-1}$ and $0.74 \mathrm{~g} \mathrm{~kg}^{-0.75}$ day $\left.^{-1}\right)$ and in the urine $\left(2.56 \mathrm{~g}\right.$ animal $^{-1}$ day $^{-1}$ and $0.24 \mathrm{~g} \mathrm{~kg}^{-0.75}$ day $\left.^{-1}\right)$. N loss via feces and urine correspond to $22.01 \%$ and $7.14 \%$ of $\mathrm{N}$ intake, totalizing 29.15\% (Table 5). MORENO et al. (2010) did not find effect on the $\mathrm{N}$ intake $\left(27.26 \mathrm{~g} \mathrm{day}^{-1}\right), \mathrm{N}$ excreted in the feces $\left(12.57 \mathrm{~g} \mathrm{day}^{-1}\right)$ and in the urine $\left(6.37 \mathrm{~g} \mathrm{day}^{-1}\right)$ in lambs fed corn or sugarcane silage in different proportions. CARVALHO et al. (2010) and CARVALHO et al. (2011) however, assessing the NB of goats and heifers fed diets containing IN sugarcane or hydrolyzed using $\mathrm{CaO}$ in different levels (zero, $0.75 \%, 1.50 \%$ and $2.25 \%$ ), found a negative effect for $\mathrm{N}$ intake for heifers, whereas it was a crescent linear effect for goats fed hydrolyzed sugarcane. They have justified the effects by a possible relation in the changes of the fermentative patterns by the use of alkaline additive $\mathrm{CaO}$. In the current study, the $\mathrm{CaO}$ level using $0.6 \%$ might have not been sufficient to change the ruminal environment or the rumen fermentative patterns and, consequently change the $\mathrm{N}$ intake.

ZEOULA et al. (2006) studying diets with different contents of rumen degradable protein (RDP) and ground corn (slow ruminal degradability) as starch source in sheep found values of $56.04 \%$ for total nitrogen loss (feces and urine). MORENO et al. (2010) found values of $68.33 \%$ for total nitrogen loss (feces and urine), whereas we found $29.15 \%$. CARVALHO et al. (2010), studying goats fed sugarcane hydrolyzed using $\mathrm{CaO}$ (zero, $0.75 \%, 1.5 \%$ and $2.25 \%$ ), found that $75.79 \%$ of the $\mathrm{N}$ intake was lost in the feces and urine.

A higher $(\mathrm{P}<0.05)$ nitrogen absorption was observed for lambs fed ANA $\left(3.00 \mathrm{~g} \mathrm{~kg}^{-0.75} \mathrm{day}^{-1}\right)$ than for lambs fed IN $\left(2.22 \mathrm{~g} \mathrm{~kg}^{-0.75} \mathrm{day}^{-1}\right)$. Non-ionized ammonia $\left(\mathrm{NH}_{3}\right)$ is absorbed by the ruminal walls but not on its ionized form $\left(\mathrm{NH}_{4}^{+}\right)$. This happens because the decrease of ruminal $\mathrm{pH}$ favors the ammonia 
Table 5 - Nitrogen $(\mathrm{N})$ intake, $\mathrm{N}$ excreted in the feces, $\mathrm{N}$ excreted in the urine and $\mathrm{N}$ balance (NB), for lambs fed in natura sugarcane or sugarcane hydrolyzed under aerobic or anaerobic conditions.

\begin{tabular}{|c|c|c|c|c|}
\hline Variable & IN & AER & ANA & $\operatorname{Pr}>F$ \\
\hline $\mathrm{g}$ animal $^{-1}$ day $^{-1}$ & $33.06 \pm 1.40$ & $37.47 \pm 3.00$ & $38.84 \pm 1.90$ & ns \\
\hline $\mathrm{g} \mathrm{kg}^{-0.75}$ day $^{-1}$ & $3.10 \pm 0.12$ & $3.50 \pm 0.27$ & $3.68 \pm 0.19$ & ns \\
\hline $\mathrm{g}_{\text {animal }}{ }^{-1}$ day $^{-1}$ & $9.32 \pm 1.82$ & $7.27 \pm 0.71$ & $7.18 \pm 0.63$ & ns \\
\hline $\mathrm{g} \mathrm{kg}^{-0.75}$ day $^{-1}$ & $0.88 \pm 0.17$ & $0.68 \pm 0.06$ & $0.68 \pm 0.06$ & ns \\
\hline$\% \mathrm{~N}$ intake & $27.97 \pm 4.85$ & $19.58 \pm 1.68$ & $18.50 \pm 1.30$ & ns \\
\hline $\mathrm{g}$ animal $^{-1}$ day $^{-1}$ & $2.36 \pm 0.31$ & $3.13 \pm 0.08$ & $2.20 \pm 0.27$ & ns \\
\hline $\mathrm{g} \mathrm{kg}^{-0.75}$ day $^{-1}$ & $0.21 \pm 0.02$ & $0.29 \pm 0.007$ & $0.21 \pm 0.02$ & ns \\
\hline$\% \mathrm{~N}$ intake & $7.20 \pm 1.08$ & $8.48 \pm 0.42$ & $5.74 \pm 0.76$ & ns \\
\hline $\mathrm{g}_{\text {animal }}{ }^{-1}$ day $^{-1}$ & $23.75 \pm 1.74$ & $\begin{array}{l}-\mathrm{N} \text { absorbed- } \\
30.20 \pm 2.75\end{array}$ & $31.67 \pm 1.62$ & ns \\
\hline $\mathrm{g} \mathrm{kg}^{-0.75}$ day $^{-1}$ & $2.22^{\mathrm{b}} \pm 0.15$ & $2.82^{\mathrm{ab}} \pm 0.25$ & $3.00^{\mathrm{a}} \pm 0.16$ & $*$ \\
\hline$\% \mathrm{~N}$ intake & $72.02 \pm 4.85$ & $80.42 \pm 1.68$ & $81.50 \pm 1.31$ & ns \\
\hline $\mathrm{g}_{\text {animal }}{ }^{-1}$ day $^{-1}$ & $21.39^{\mathrm{b}} \pm 1.70$ & $\begin{array}{c}\text { retained or NB } \\
27.06^{\mathrm{ab}} \pm 2.68\end{array}$ & $29.46^{\mathrm{a}} \pm 1.66$ & * \\
\hline $\mathrm{g} \mathrm{kg}^{-0.75}$ day $^{-1}$ & $2.00^{\mathrm{b}} \pm 0.15$ & $2.53^{\mathrm{ab}} \pm 0.24$ & $2.78^{\mathrm{a}} \pm 0.16$ & $*$ \\
\hline$\% \mathrm{~N}$ intake & $64.82 \pm 4.54$ & $71.94 \pm 1.85$ & $75.75 \pm 1.47$ & ns \\
\hline $\mathrm{N}$ retained/ $\mathrm{N}$ intake & $0.64 \pm 0.04$ & $0.72 \pm 0.01$ & $0.75 \pm 0.01$ & ns \\
\hline $\mathrm{N}$ retained/N absorbed & $0.90 \pm 0.01$ & $0.89 \pm 0.006$ & $0.92 \pm 0.009$ & ns \\
\hline
\end{tabular}

$\mathrm{IN}=$ in natura sugarcane + concentrate, $\mathrm{AER}=$ sugarcane hydrolyzed using $0.6 \% \mathrm{CaO}$ under aerobic condition + concentrate, $\mathrm{ANA}=$ sugarcane hydrolyzed using $0.6 \% \mathrm{CaO}$ under anaerobic condition + concentrate. Tuket test $(*=\mathrm{P}<0.05$, ns $=$ non-significance $)$.

Source: elaboration of the authors.

ionization and reduces its absorption (BERCHIELLI et al., 2011). The supply of sugarcane hydrolyzed using $\mathrm{CaO}$ could have changed the ruminal environment resulting in a higher $\mathrm{pH}$, therefore increasing the $\mathrm{N}$ absorption compared to lambs fed IN. AER did not show statistical difference in $\mathrm{N}$ absorption $(2.82 \mathrm{~g}$ $\mathrm{kg}^{-0.75}$ day $^{-1}$ ) but it showed a tendency of a higher $\mathrm{N}$ absorption compared to IN $\left(2.22 \mathrm{~g} \mathrm{~kg}^{-0.75} \mathrm{day}^{-1}\right)$.

Non-protein nitrogen (NPN) from the diet is rapidly available for the ruminal microorganisms and converted into microbial protein. A portion of the NPN is absorbed as non-ionized ammonia $\left(\mathrm{NH}_{3}\right)$ and sent to the liver, via enterohepatic circulation, where ammonia is converted into urea. The urea can be either recycled via blood stream to the saliva, via diffusion to the rumen ( $\mathrm{N}$ absorbed) or it can be excreted in the urine. The $\mathrm{N}$ recycling process starts when the $\mathrm{NH}_{3}$ is absorbed by the rumen walls (BERCHIELLI et al., 2011). There is a possibility that there was a high rate of $\mathrm{N}$ recycled in the current study, once the $\mathrm{N}$ absorption (28.54g day $^{-1}$ ) was higher than other studies, e.g. 14.69 and $18.25 \mathrm{~g} \mathrm{day}^{-1}$ found by MORENO et al. (2010) and CARVALHO et al. (2010), respectively. Moreover, the $\mathrm{N}$ excreted in the urine was lower $\left(2.56 \mathrm{~g}\right.$ day $\left.^{-1}\right)$ compared to $11.30,6.37$ and $12.28 \mathrm{~g}$ day $^{-1}$ found by ZEOULA et al. (2006), MORENO et al. (2010) and CARVALHO et al. (2010).

The $\mathrm{N}$ excretion in the urine $(7.14 \%$ of $\mathrm{N}$ intake) was lower than the $\mathrm{N}$ excretion in the feces (22.01\%) in the current study. ZEOULA et al. (2003), used fed diets containing different levels of cassava by-product meal (fast ruminal degradation) replacing corn (slow ruminal degradation) and soybean meal as a protein source, also found lower $\mathrm{N}$ excretion in the urine $(30.90 \%)$ than the $\mathrm{N}$ excretion in the feces $(35.2 \%)$. The soybean meal as source of protein $\mathrm{N}$ and urea as source of non-protein $\mathrm{N}$, besides the use of sugarcane as source of readily fermentable carbohydrate in the rumen might have influenced the synchronization with the $\mathrm{N}$ released, increasing the $\mathrm{N}$ retained (NB) $\left(29,46 \mathrm{~g} \mathrm{day}^{-1}\right.$ and $2,78 \mathrm{~g} \mathrm{~kg}^{-0.75}$ day $^{-1}$ ) by a higher $\mathrm{N}$ recycling. According to ZEOULA et al. (2006) this available energy generated a $21 \%$ 
increase of $\mathrm{N}$ retained because it seemed to have provided a better synchronization of the $\mathrm{N}$ released with the readily available energy of the rumen.

We found NB values of $25.97 \mathrm{~g} \mathrm{day}^{-1}$ and $2.44 \mathrm{~g} \mathrm{~kg}^{-0.75}$ day $^{-1}$ which were higher than values found by MORENO et al. (2010) who reported $8.55 \mathrm{~g}$ day $^{-1}$ and $0.67 \mathrm{~g} \mathrm{~kg}^{-0.75} \mathrm{day}^{-1}$. This difference is due to the higher $\mathrm{N}$ intake and a lower $\mathrm{N}$ excreted in feces and urine obtained in our study. The sugarcane hydrolysis using $\mathrm{CaO}$ (alkaline additive) could have changed the fermentative ruminal environment and reduced the nitrogen balance (CARVALHO et al., 2011); our results, however, show that the $0.6 \% \mathrm{CaO}$ content used in the sugarcane hydrolysis did not have a negative effect in the ruminal degradation. Conversely, the readily available carbohydrates in the rumen coming from the sugarcane resulted in a higher $\mathrm{N}$ retained $(\mathrm{NB})$.

\section{CONCLUSION}

As roughage, the sugarcane hydrolyzed under anaerobic condition in the lamb diet, optimizes the NB and is more efficient to improve the digestibility of NDFap, HEM and OM compared to in natura sugarcane. Whereas sugarcane hydrolyzed under aerobic condition was as efficient as sugarcane hydrolyzed under anaerobic condition and in natura.

\section{ETHICS AND BIOSECURITY COMMITTEE}

This research is in accordance with the Ethical Principles in Animal Experimentation, and was approved by Committee of the Use of Animals, protocol number 011855/12.

\section{REFERENCES}

ASSOCIATION OF OFFICIAL ANALYTICAL CHEMISTS (AOAC). Official methods of analysis. 15.ed. Washington, D.C., 1990. $1298 \mathrm{p}$

BERCHIELLI, T.T. et al. Nutrição de ruminantes. Jaboticabal: Funep, 2011. 616p.

CARVALHO, G.G.P. et al. Metabolismo de nitrogênio em novilhas alimentadas com dietas contendo cana-de-açúcar tratado com óxido de cálcio. Revista Brasileira de Zootecnia, v.40, n.3, p.622629, jul. 2011. Available from: <http://dx.doi.org/10.1590/S151635982011000300022>. Accessed: 13 ago. 2013. doi: 10.1590/ S1516-35982011000300022.

CARVALHO, G.G.P. et al. Balanço de nitrogênio, concentração de ureia e síntese de proteína microbiana em caprinos alimentados com dietas contendo cana-de-açúcar tratada com óxido de cálcio. Revista Brasileira de Zootecnia, v.39, n.10, p.2253-2261, out. 2010. Available from: <http://dx.doi.org/10.1590/S151635982010001000022>. Accessed: 13 ago. 2013. doi: 10.1590/ S1516-35982010001000022.

DETMANN, E. et al. Métodos para análise de alimentos Visconde do Rio Branco: Instituto Nacional de Ciência e Tecnologia de Ciência Animal, 2012. 214p.

FREITAS, A.W.P. et al. Consumo de nutrientes e desempenho de ovinos alimentados com dietas à base de cana-de-açúcar hidrolisada. Pesquisa Agropecuária Brasileira, v.43. n.11, p.1569-1574, nov. 2008. Available from: <http://dx.doi.org/10.1590/S0100204X2008001100016>. Accessed: 10 jun. 2013. doi: 10.1590/ S0100-204X2008001100016.

MARAIS, P.J. Use of markers. In: D'MELLO, J.P.F. Farm animal metabolism and nutrition: critical reviews. Wallingford: $\mathrm{CAB}$ International, 2000. p.255-277.

MORENO, G.M.B. et al. Desempenho, digestibilidade e balanço de nitrogênio em cordeiros alimentados com silagem de milho ou cana-de-açúcar e dois níveis de concentrado. Revista Brasileira de Zootecnia, v.39, n.4, p.853-860, abr. 2010. Available from: <http:// dx.doi.org/10.1590/S1516-35982010000400022>. Accessed: 03 mar. 2013. doi: 10.1590/S1516-35982010000400022.

NATIONAL RESEARCH COUNCIL (RNC). Nutrient requirements of small ruminants: sheep, goats, cervids, and new world camelids. 6.ed. Washington, DC: National Academy, 2007. $384 \mathrm{p}$.

OLIVEIRA, M.D.S. Cana-de-açúcar hidrolisada na alimentação de bovinos. Jaboticabal: Funep, 2010. 115p.

RABELO, C.H.S. et al. Estabilidade aeróbia de cana-de-açúcar in natura hidrolisada com cal virgem. Ciência Animal Brasileira, v.12, n.2, p.257-265, abr./jun. 2011.

STATISTICAL ANALYSIS SYSTEMS (SAS). 2001. User's guide: Statistics, Version 9.0 Cary, 2002.

SUNDSTOL, J.; OWEN, E. Straw and other fibrous by-products as feed. Elsevier, 1984. 630p.

VAN SOEST, P.J. et al. Methods for dietary fiber, neutral detergent fiber, and nonstarch polysaccharides in relation to animal nutrition. Journal of Dairy Science, v.74, n.12, p.3583-3597, oct. 1991.

ZEOULA, L.M. et al. Substituição do milho pela farinha de varredura de mandioca (Manihot esculenta crantz) em rações de ovinos: consumo, digestibilidade, balanços de nitrogênio e energia e parâmentros ruminais. Revista Brasileira de Zootecnia, v.32, n.2, p.491-502, fev. 2003.

ZEOULA, L.M. et al. Digestibilidade e balanço de nitrogênio de rações com diferentes teores de proteína degradável no rúmen e milho moído como fonte de amido em ovinos. Revista Brasileira de Zootecnia, v.35, n.5, p.2179-2186, mai. 2006. 